\title{
Case Report \\ Guillain-Barré Syndrome with Fatal Outcome during HIV-1-Seroconversion: A Case Report
}

\author{
Emanuele Pontali, Marcello Feasi, Maria Paola Crisalli, and Giovanni Cassola \\ Department of Infectious Diseases, Galliera Hospital, Via Volta, 16128 Genoa, Italy \\ Correspondence should be addressed to Emanuele Pontali, pontals@yahoo.com
}

Received 7 May 2011; Accepted 21 June 2011

Academic Editors: M. Murhekar and W. I. van der Meijden

Copyright ( $) 2011$ Emanuele Pontali et al. This is an open access article distributed under the Creative Commons Attribution License, which permits unrestricted use, distribution, and reproduction in any medium, provided the original work is properly cited.

Guillain-Barré syndrome (GBS) is an acute or subacute peripheral polyneuropathy characterized by symmetrical muscle weakness. Its occurrence has been reported during acute HIV seroconversion since 1985. Among HIV-infected subjects, GBS has generally a favourable outcome. We report a case of GBS with fatal outcome during HIV seroconversion.

\section{Introduction}

Guillain-Barré syndrome (GBS) is an acute or subacute peripheral polyneuropathy characterized by symmetrical muscle weakness occurring in the absence of identifiable causes of genetic, metabolic, or toxic origin. The characteristic presentation of the syndrome involves symmetrical paresis or paresthesia of an ascending nature, with reduction or loss of deep reflexes and variable autonomic dysfunction. Signs and symptoms observed in the course of GBS are extremely variable. The observed dysfunctions can be motor, sensory, or autonomic (Table 1) [1, 2]. Diagnostic approach to GBS is based on clinical, laboratory, and electrophysiological criteria (Table 1). Progressive motor weakness and areflexia are prime requirements for diagnosis. Cerebrospinal fluid analysis is the only laboratory criterion. Guillain-Barré syndrome onset is associated with a history of infection, mainly of viral origin. Many patients with GBS describe a febrile illness followed by an ascending paralysis occurring days to weeks later. Actually, symptoms are preceded by an antecedent event in about two thirds of cases. Respiratory infections are the commonest, reported in about $40 \%$ of cases within one month before the onset of the disease. About $20 \%$ of patients experience gastroenteritis as the antecedent cause [1]. Since 1985, several cases of the disease among HIVinfected patients have been reported, with GBS occurring concomitantly with HIV seroconversion or during the initial phases of infection [3-10]. In fact, HIV infection is one of the most common causes of this syndrome in African countries, India, and other developing countries. In addition, cases of GBS associated with the immunological reconstitution induced by the use of antiretroviral therapy have also been reported $[11,12]$. GBS has frequently a favourable outcome in HIV-infected subjects [3-12].

To our knowledge, we report the first case of GBS with fatal outcome during HIV seroconversion.

\section{Case Presentation}

A 56-year-old man who had already been observed at our department for acute B (1988) and A (2000) hepatitis was evaluated at our Outpatient Unit (OPD). His medical history included viral encephalitis at age 6, chronic inflammatory bowel disease (treated with mesalazine), and past surgery for discal hernia. Homosexual intercourse with risk for HIV transmission was reported. He had tested HIV-negative about six-months before.

When presenting at our OPD, the patient reported the occurrence of fever (up to $38^{\circ} \mathrm{C}$ ) and diffused maculopapular rash about one month earlier. At that time, headache and intense pulsatory pain at shoulders had also been present for a few days. Blood tests showing evidence of probable acute viral infection had also been performed. During the 
TABLE 1: Characteristics clinical features of Guillain-Barré syndrome and recommended diagnostic investigations.

\begin{tabular}{|c|c|c|}
\hline $\begin{array}{l}\text { Clinical features of } \\
\text { Guillain-Barré syndrome }\end{array}$ & & Recommended diagnostic investigations \\
\hline \multirow[t]{4}{*}{ Motor dysfunctions } & $\begin{array}{l}\text { Symmetrical limb weakness: proximal, distal or glob- } \\
\text { al; typically distal to proximal and rapidly ascending }\end{array}$ & Cerebrospinal fluid examination \\
\hline & $\begin{array}{l}\text { Muscle weakness (especially neck and respiratory } \\
\text { muscles) or wasting (especially limbs) }\end{array}$ & Electrophysiological study \\
\hline & $\begin{array}{l}\text { Cranial nerve palsies: III-VII, IX-XII (most typical: } \\
\text { facial palsy) }\end{array}$ & Stool culture for C. jejuni \\
\hline & Areflexia & $\begin{array}{l}\text { Serology to C. jejuni, Cytomegalovirus, Epstein- } \\
\text { Barr Virus, Herpes Simplex Virus, HIV, M. } \\
\text { pneumoniae }\end{array}$ \\
\hline \multirow[t]{4}{*}{ Sensory dysfunctions } & Pain & Magnetic resonance imaging \\
\hline & Numbness, paraesthesiae & Electrocardiogram \\
\hline & Ataxia & Blood pressure monitoring \\
\hline & $\begin{array}{l}\text { Decrease or loss in proprioception, vibration, touch, } \\
\text { and pain distally }\end{array}$ & Autonomic function tests \\
\hline \multirow[t]{11}{*}{ Autonomic dysfunctions } & Sinus tachycardia and bradycardia & Antiganglioside antibodies \\
\hline & Other cardiac arrhythmias & $\begin{array}{l}\text { Biochemical screening: urea, electrolytes, liver } \\
\text { enzymes }\end{array}$ \\
\hline & Hypertension and postural hypotension & Full blood count \\
\hline & Wide fluctuations of pulse and blood pressure & $\begin{array}{l}\text { Erythrocyte sedimentation rate or C-reactive } \\
\text { protein }\end{array}$ \\
\hline & Hypersalivation & \\
\hline & Anhydrosis or excessive sweating & \\
\hline & Urinary sphincter disturbances & \\
\hline & Gastric dysmotility & \\
\hline & Constipation or diarrhea & \\
\hline & $\begin{array}{l}\text { Abnormal vasomotor tone causing venous pooling } \\
\text { and facial flushing }\end{array}$ & \\
\hline & Tonic pupils & \\
\hline Others & Papilloedema & \\
\hline
\end{tabular}

three days before presentation at our OPD, he had been showing progressive asthenia, with increasing weakness at all limbs, dysarthria, and dysphagia. He was immediately hospitalised.

At entry he was confused, with amimic face, bilateral facial palsy (prevalent on the right), all limbs weakness (right side more than left), generalized hyporeflexia or areflexia at all limbs, anhysocoria (left > right), and heart rate $90 \mathrm{bpm}$, with blood pressure (BP) ascending in a couple of hours from $110 / 70$ to $170 / 100$. Skin rash was not anymore visible.

Among blood tests performed there was a mild increase in liver enzymes (complete results in Table 2). Antibodies for HIV-1 were detected, and confirmation test was positive. CD4+ lymphocyte count was $710 / \mathrm{mm}^{3}$ (45\%), and viral load was 4,400 copies of HIV-RNA/mL.

One day after hospitalisation MRI scan of brain and truncus showed no specific signs (Table 2). The neurologist consultant then recommended lumbar puncture in the suspect of GBS. Lumbar puncture was performed on the third day. CSF examination showed 3 cells $/ \mathrm{mm}^{3}$ and increased protein level $(291 \mathrm{mg} / \mathrm{dL})$, a pattern compatible with GBS [1]. Electroencephalogram was normal. BP was irregular, but gradually under control with antihypertensive drugs. Electrophysiological study was scheduled.

On the fifth day, the patient presented a worsening of limb weakness (both proximal and distal); anhysocoria was not anymore visible. He was started on intravenous immunoglobulins (IVIG) $(400 \mathrm{mg} / \mathrm{kg} /$ day). Three days later he suddenly died because of cardiac arrest; prolonged resuscitation procedures were ineffective.

\section{Discussion}

The mechanisms proposed for GBS in HIV-1-infected patients include a direct action of HIV-1 on the nerves by neurotropic strains, or autoimmune mechanisms, with the formation of antibodies against myelin secondary to the abnormal immunoregulation determined by HIV infection [13]. The onset of GBS in this case coincided with the acute retroviral syndrome of HIV, during the phase of initial immune reconstitution following serologic conversion, as observed in other cases reported in the literature [6, 7]. Although GBS in HIV-infected subjects has generally 
TABLE 2: Results of diagnostic investigations during hospitalization.

\begin{tabular}{|c|c|c|}
\hline \multicolumn{3}{|l|}{$\begin{array}{l}\text { Laboratory } \\
\text { investigations }\end{array}$} \\
\hline \multirow[t]{11}{*}{ Blood } & alanine-aminotransferase (AST) & $80 \mathrm{U} / \mathrm{L}(2 \times \mathrm{ULN})$ \\
\hline & aspartate-aminotransferase (ALT) & $103 \mathrm{U} / \mathrm{L}(>2.5 \mathrm{ULN})$ \\
\hline & Total bilirubin & $1.8 \mathrm{mg} / \mathrm{dL}($ normal < 1.2$)$ \\
\hline & lactic dehydrogenase (LDH) & $603 \mathrm{U} / \mathrm{L}($ normal < 460) \\
\hline & HIV-Ab (including RIBA) & Positive \\
\hline & CD4+ cell count and \% & $710 / \mathrm{mL} ; 45 \%$ \\
\hline & CD8+ cell count and \% & $595 / \mathrm{mL} ; 37 \%$ \\
\hline & $\mathrm{CD} 4+/ \mathrm{CD} 8+$ ratio & 1.2 \\
\hline & HIV viral load & $\begin{array}{l}\text { 4,400 copies of HIV-RNA/ } \\
\mathrm{mL}\end{array}$ \\
\hline & Hepatitis B virus markers & $\begin{array}{l}\text { HBs-Ab, total } \mathrm{HBcAb} \text {, and } \\
\text { HBeAb: positive }\end{array}$ \\
\hline & $\begin{array}{l}\text { haemochrome, C-reactive protein, blood sugar, uraemia, creatinine, } \gamma \text {-glutamil- } \\
\text { transpeptidase, alkaline phosphatase, creatine-phosphokinase, amylase, lipase, } \\
\text { triglycerids, ions, protidogram, immunoglobulins (total IgG, IgM, IgA), Hepatitis } \\
\text { C Virus-Ab, coagulation tests, complement fractions (C3 and C4), ANA, syphilis } \\
\text { tests (TPHA and RPR), and urine analysis }\end{array}$ & $\begin{array}{l}\text { Negative or within normal } \\
\text { ranges }\end{array}$ \\
\hline \multirow[t]{5}{*}{$\begin{array}{l}\text { Cerebrospinal } \\
\text { fluid }\end{array}$} & Cells & 3/mL (all mononuclear cells) \\
\hline & Proteins & $291 \mathrm{mg} / \mathrm{dL}$ \\
\hline & Protein analysis & $\begin{array}{l}\text { Barrier damage with propor- } \\
\text { tional increase in IgG and } \\
\text { albumin }\end{array}$ \\
\hline & HIV viral load & Not detectable \\
\hline & $\begin{array}{l}\text { Glucose, oligoclonal IgG bands, culture for bacteria and fungi, and syphilis tests } \\
\text { (TPHA and RPR) }\end{array}$ & $\begin{array}{l}\text { Negative or within normal } \\
\text { ranges }\end{array}$ \\
\hline
\end{tabular}

a favourable outcome, rapid worsening of clinical conditions such as respiratory failure has been reported [7].

Both plasmapheresis and IVIG have been used to treat GBS in HIV-infected individuals [14-16]. The reported results have ranged from ineffective and mild benefit to good response $[6,14]$. Nevertheless, IVIG currently remains the preferred choice in treating GBS. IVIG is preferred to plasmapheresis because of greater convenience, with overall comparable cost and equal efficacy $[1,17]$.

Twenty-five percent of all GBS patients require ventilator support of some type, and many of them require access to ICU [1]. Nevertheless, outcomes after ICU care were reported to be similar in HIV-positive and HIV-negative patients with GBS [18].

Unfortunately, in our case the rapid fatal evolution did not allow for ICU support. Cases with autonomic disturbances have been reported with similar evolution. Many deaths due to GBS are in fact attributed to autonomic disturbances; cardiac arrest being the most common cause, responsible for $20-30 \%$ of deaths [2]. Approximately $25 \%$ of deaths occur within the first week of onset of GBS.

Some conclusions can be drawn from this case. First, it is necessary to consider the possibility of GBS when patients are diagnosed with a symptomatic acute HIV syndrome. Patients could be advised to promptly report any neurological symptom or sign suggestive of GBS. This would allow for early diagnosis and proper timely management, including treatment and support. Second, the opposite is also true: in cases of GBS, HIV infection should be considered and searched. Last, but not less important, HIV-infected patients with GBS should be accurately monitored, because serious complications and fatal outcome of the disease are possible as in the HIV-uninfected.

\section{References}

[1] U. Seneviratne, “Guillain-Barré syndrome," Postgraduate Medical Journal, vol. 76, no. 902, pp. 774-782, 2000.

[2] K. McClellan, E. Armeau, and T. Parish, "Recognizing Guillain-Barré syndrome in the primary care setting," The Internet Journal of Allied Health Sciences and Practice, vol. 5, no. 1, 2007.

[3] L. Hagberg, B. E. Malmvall, L. Svennerholm, K. Alestig, and G. Norkrans, "Guillain-Barré syndrome as an early manifestation of HIV central nervous system infection," Scandinavian Journal of Infectious Diseases, vol. 18, no. 6, pp. 591-592, 1986.

[4] C. A. Thornton, A. S. Latif, and J. C. Emmanuel, "GuillainBarré syndrome associated with human immunodeficiency virus infection in Zimbabwe," Neurology, vol. 41, no. 6, pp. 812-815, 1991.

[5] T. H. Brannagan III and Y. Zhou, "HIV-associated GuillainBarré syndrome," Journal of the Neurological Sciences, vol. 208, no. 1-2, pp. 39-42, 2003. 
[6] S. Kumar, M. Alexander, V. Markandeyulu, and C. Gnanamuthu, "Guillain-Barré syndrome presenting in the anti-HIV seroconversion period," Neurology India, vol. 51, no. 4, p. 559, 2003.

[7] S. H. Ting, J. H. Yeh, and H. C. Chiu, "Guillain-Barré syndrome with HIV infection: a case report," Acta Neurologica Taiwanica, vol. 12, no. 3, pp. 139-142, 2003.

[8] A. Millogo, A. Sawadogo, D. Lankoande, and A. B. Sawadogo, "Guillain-Barré syndrome in HIV-infected patients at BoboDioulasso Hospital (Burkina Faso)," Revue Neurologique, vol. 160, no. 5, pp. 559-562, 2004.

[9] H. K. Aggarwal, D. Chakrabarti, N. Nand, Sonia, K. Bharti, and R. P. Verma, "HIV infection presenting as Guillain-Barré syndrome," Journal, Indian Academy of Clinical Medicine, vol. 6, no. 4, pp. 341-342, 2005.

[10] G. de Castro, P. G. Bastos, R. Martinez, and J. F. de Castro Figueiredo, "Episodes of Guillain-Barré syndrome associated with the acute phase of HIV-1 infection and with recurrence of viremia," Arquivos de Neuro-Psiquiatria, vol. 64, no. 3, pp. 606-608, 2006.

[11] P. Makela, L. Howe, S. Glover, I. Ferguson, A. Pinto, and M. Gompels, "Recurrent Guillain-Barré syndrome as a complication of immune reconstitution in HIV," Journal of Infection, vol. 44, no. 1, pp. 47-49, 2002.

[12] P. J. Piliero, D. G. Fish, S. Preston et al., "Guillain-Barré syndrome associated with immune reconstitution," Clinical Infectious Diseases, vol. 36, no. 9, pp. e111-e114, 2003.

[13] M. C. Dalakas and G. H. Pezeshkpour, "Neuromuscular diseases associated with human immunodeficiency virus infection," Annals of Neurology, vol. 23, supplement 1, pp. S38S48, 1988 .

[14] J. R. Berger, J. A. Difini, M. A. Swerdloff, and D. R. Ayyar, "HIV seropositivity in Guillain-Barré syndrome," Annals of Neurology, vol. 22, no. 3, pp. 393-394, 1987.

[15] R. P. Kleyweg, F. G. A. van der Meche, and J. Meulstee, "Treatment of Guillain-Barré syndrome with high-dose gammaglobulin," Neurology, vol. 38, no. 10, pp. 1639-1641, 1988.

[16] K. M. Hassan and I. Mathew, "Guillain-Barré syndrome in an HIV seropositive subject," The Journal of the Association of Physicians of India, vol. 48, no. 12, p. 1214, 2000.

[17] Plasma Exchange/Sandoglobulin Guillain-Barré Syndrome Trial Group, "Randomised trial of plasma exchange, intravenous immunoglobulin, and combined treatments in Guillain-Barré syndrome,” The Lancet, vol. 349, no. 9047, pp. 225-230, 1997.

[18] G. K. Schleicher, A. Black, A. Mochan, and G. A. Richards, "Effect of human immunodeficiency virus on intensive care unit outcome of patients with Guillain-Barré syndrome," Critical Care Medicine, vol. 31, no. 6, pp. 1848-1850, 2003. 


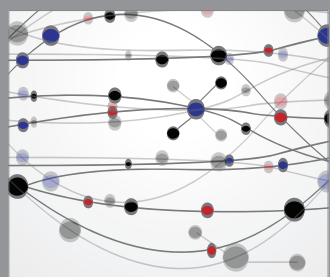

The Scientific World Journal
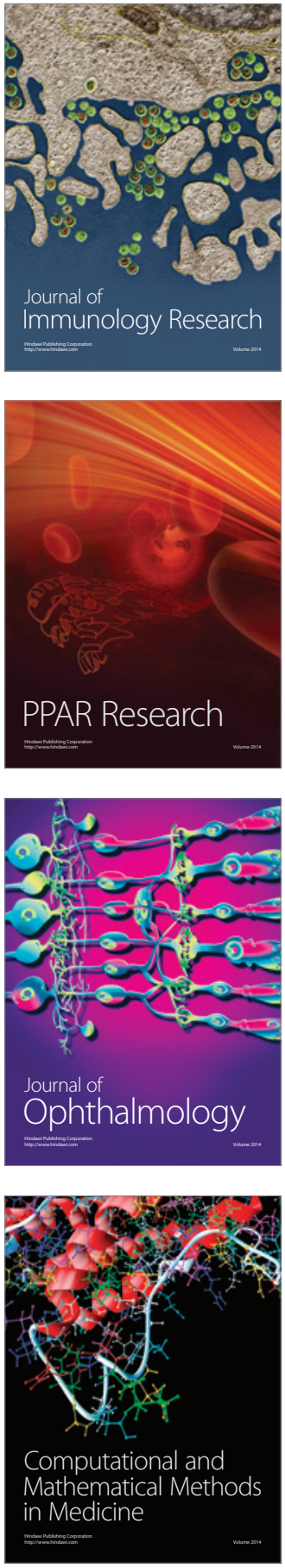

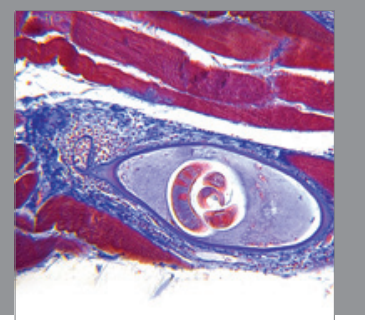

Gastroenterology

Research and Practice
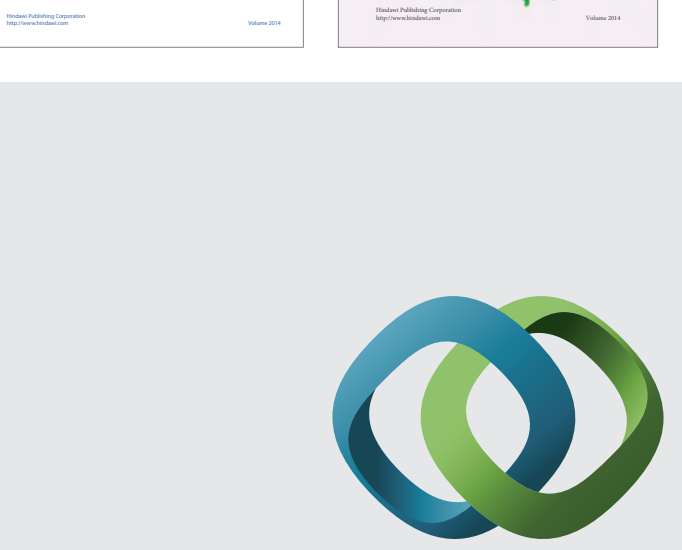

\section{Hindawi}

Submit your manuscripts at

http://www.hindawi.com
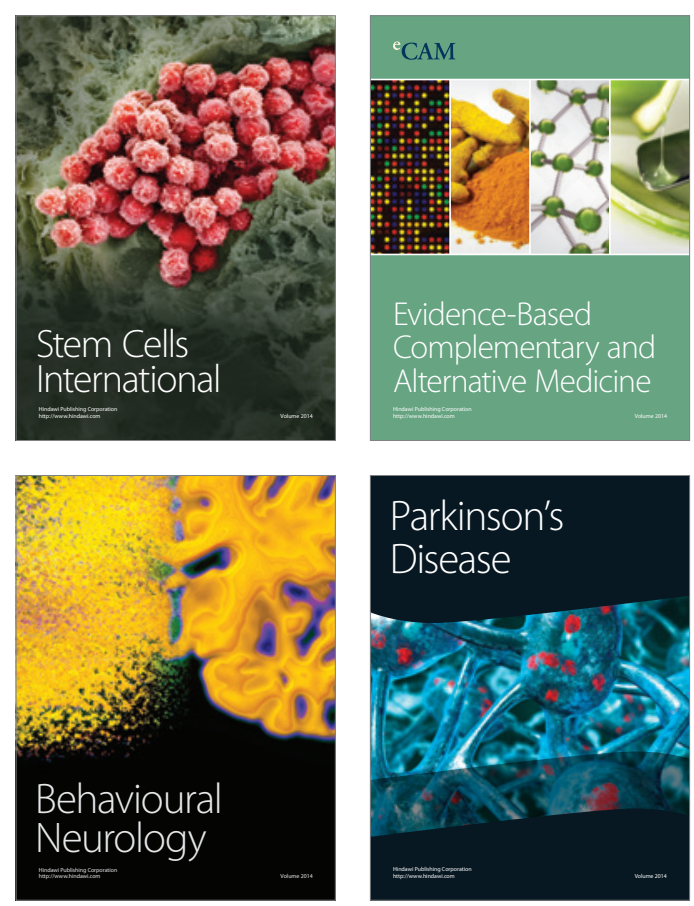

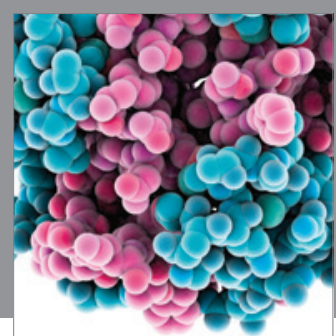

Journal of
Diabetes Research

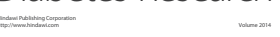

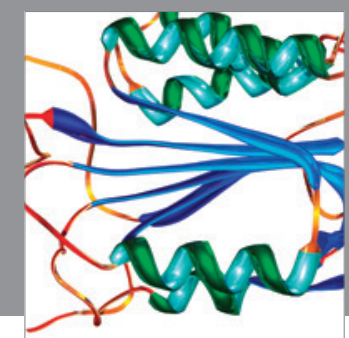

Disease Markers
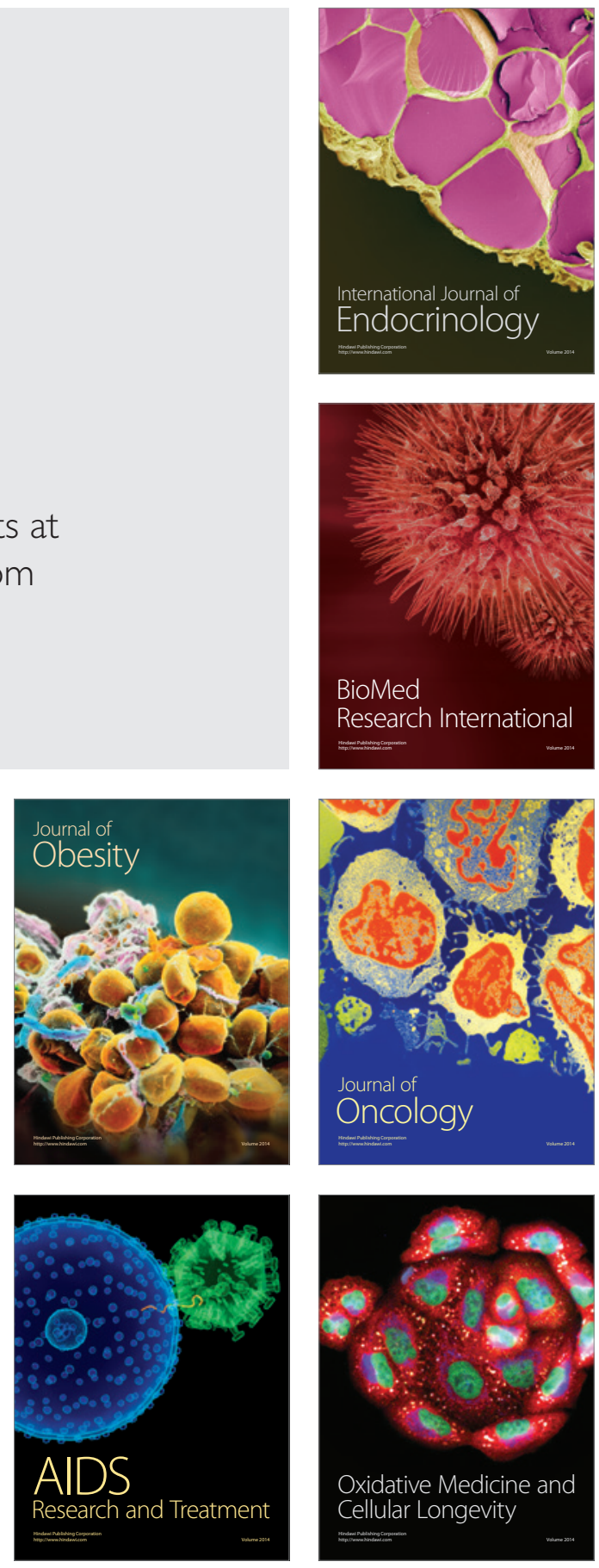